\title{
Chromosomal aberrations in mouse lymphocytes exposed in vivo and in vitro to aliphatic epoxides
}

\author{
L. Das ${ }^{\text {a }}$, S.K. Das ${ }^{\text {b }}$, E.H.Y. Chu ${ }^{\text {a }}$ and J.E. Sinsheimer ${ }^{\text {b }}$ \\ ${ }^{a}$ Department of Human Genetics and ${ }^{b}$ College of Pharmacy, University of Michigan, Ann Arbor, MI 48109, USA \\ (Received 22 June 1992) \\ (Revision received 31 August 1992) \\ (Accepted 11 September 1992)
}

Keywords: Aliphatic epoxides; Epoxides, aliphatic; Lymphocyte tests; Chromosomal aberrations

\section{Summary}

Mouse lymphocytes in vivo or in vitro were exposed for $24 \mathrm{~h}$ to 4 aliphatic epoxides, glycidyl 1-naphthyl ether, glycidyl 4-nitrophenyl ether, 1-naphthylpropylene oxide and trichloropropylene oxide (TCPO), and tested for the induction of chromosomal aberrations (CA). These epoxides were among the most genotoxic aliphatic epoxides in our previous studies. With the exception of TCPO, the test epoxides caused significant increases in $\mathrm{CA}$ in vivo compared to a negative control. There were concentration related increases in CA for all 4 epoxides in vitro and TCPO produced the greatest cellular toxicity and genotoxic effects towards cultured lymphocytes. The difference in the order of genotoxicity for the two test systems can be explained on the basis of a much shorter half-life for TCPO than for the other epoxides.

Aliphatic epoxides are important industrial and laboratory reagents and can arise as metabolic products from their unsaturated precursors. Because these epoxides can be strong alkylating agents, their in vitro mutagenicity and in vivo genotoxicity is of interest (Manson, 1980; Ehrenberg and Hussain, 1981). The present study is an extension of our previous investigations of structure-mutagenicity and in vivo genotoxicity relationships for aliphatic epoxides (Wade et al., 1978; Neau et al., 1982; Djuric et al., 1986; Rosman et al., 1987, 1988; Giri et al., 1989, 1990).

Correspondence: Dr. J.E. Sinsheimer, College of Pharmacy, University of Michigan, Ann Arbor, MI 48109-1065, USA.
There is information in the literature on cellculture chromosomal assays for a limited number of aliphatic epoxides. Several investigators have confirmed the genotoxicity of styrene oxide using such assays (Norppa et al., 1981; Nishi et al., 1984; DeRaat, 1978). The induction of CA by ethylene oxide has been observed in human lymphocytes (Ehrenberg and Hallstrom, 1967; Abrahams, 1980; Högstedt et al., 1983). Also, elevated frequencies of sister-chromatid exchange (SCE) were observed in the lymphocytes of workers (Garry et al., 1979; Abrahams, 1980; Lerda and Rizzi, 1992) and with rats (Kligerman et al., 1983) exposed to ethylene oxide. Högstedt et al. (1990) found that the genotoxicity of propylene oxide was lower than that of ethylene oxide in human 
lymphocytes which parallels the previous findings of Lynch et al. (1984) in the lymphocytes of monkeys. The metabolites of 1,3-butadiene, 3,4epoxy-1-butene and 1,2:3,4-diepoxybutane were found to be active in CHO cells and in human lymphocytes (Sasiadek et al., 1991 a,b)

The aim of the present investigation is to study the genotoxic effects of 4 aliphatic epoxides by analysis of $\mathrm{CA}$ in mice whole-blood lymphocytes using in vivo/in vitro and in vitro short-term culture tests. The epoxides selected for comparison are glycidyl 1-naphthyl ether, glycidyl 4nitrophenyl ether, 1-naphthylpropylene oxide and 3,3,3-trichloropropylene oxide. These compounds were among the most mutagenic aliphatic epoxides we had previously tested in the Ames Salmonella test (Giri et al., 1989). They were also of interest for comparison to their CA results in bone-marrow cells and DNA strand-break assays of liver cells following intraperitoneal (i.p.) administration to mice (Giri et al., 1990).

\section{Materials and methods}

\section{Animals}

Male C57BL/6J mice (2-4 months old; $25-30$ g) were obtained from Jackson Laboratory (Bar Harbor, ME) and were provided rodent lab chow (Purina) and water ad libitum. They were kept 5 per cage and housed 4-5 days prior to the start of the experiment. Ambient temperature of the animal room was controlled at $72-74^{\circ} \mathrm{F}$ with relative humidity of $25-50 \%$ and a 12 -h photoperiod (light cycle 0600 to $1800 \mathrm{~h}$ ). Bedding consisted of sterilized hardwood chips (Bed-O'-cobs, Anderson Industrial Products Division, Maumee, $\mathrm{OH}$ ).

\section{Chemicals}

Cyclophosphamide monohydrate [6055-19-2] (CP) and ethyl methanesulfonate [62-50-0] (EMS) were purchased from Sigma Chemical Co. (St. Louis, MO). Dimethyl sulfoxide 99.9\% (DMSO) and 3,3,3-trichloropropylene oxide [3083-23-6] (TCPO) were obtained from Aldrich Chemical Co. (Milwaukee, WI). 1,2-Epoxy-3-( $p$-nitrophenoxy)propane [5255-75-4] (glycidyl 4-nitrophenyl ether, GNPE) was obtained from Eastman Kodak Co. (Rochester, NY) and purified by repeated recrystallization from ethanol. Glycidyl 1-naphthyl ether [2461-42-9] (GNE) and 1-naphthylpropylene oxide [68884-32-2] (NPO) were prepared in this laboratory (Rosman et al., 1987).

\section{In vivo / in vitro lymphocyte assays}

Epoxides ( $25 \mathrm{mg} / \mathrm{kg}$ body weight) in DMSO ( 2 $\mathrm{ml} / \mathrm{kg}$ ) were injected i.p. into mice while negative control mice received only DMSO $(2 \mathrm{ml} / \mathrm{kg})$ and positive control mice were injected with CP (25 $\mathrm{mg} / \mathrm{kg}$ in DMSO). 3 mice were used for each test compound and for the controls with 2 culture tubes prepared from each animal. After $24 \mathrm{~h}$, mice were anesthetized with metafane (methoxyflurane; Pitman-Moore, Washington, NJ) and blood was drawn by cardiac puncture. Culture tubes were prepared just before inoculation with blood $(0.2 \mathrm{ml})$ following the method of Davisson and Akeson (1987). Each culture tube contained $0.95 \mathrm{ml}$ of supplemented medium, fetal bovine serum $(0.15 \mathrm{ml}$; Gibco), $50 \mu \mathrm{g} / \mathrm{ml}$ solution of lipopolysaccharide $(0.1 \mathrm{ml}$; Sigma $)$ and $60 \mu \mathrm{g} / \mathrm{ml}$ solution of purified phytohemagglutinin $(0.15 \mathrm{ml}$; Burroughs Wellcome, Greenville, NC). Supplemented medium was prepared with $100 \mathrm{ml}$ of medium (RPMI 1640, Gibco, Gaithersburg, MD), $1.2 \mathrm{ml}$ of $200 \mathrm{mM}$ glutamine (Gibco), $1 \mathrm{ml}$ of a mixture of penicillin $(100 \mathrm{IU} / \mathrm{ml})$ and streptomycin $(100 \mu \mathrm{g} / \mathrm{ml})$ (Irvine Scientific, Santa Ana, CA),

After inoculation with blood, the tubes were incubated for $42 \mathrm{~h}$ in a humidified $5 \% \mathrm{CO}_{2}$ atmosphere at $37^{\circ} \mathrm{C}$. Colcemid $(0.3 \mu \mathrm{g}$, Sigma $)$ was added 2-3 $\mathrm{h}$ before hypotonic treatment with $\mathrm{KCl}(0.075 \mathrm{M}$ for $20 \mathrm{~min})$. Then the cells were fixed in acetic acid:methanol $(1: 3)$. Samples of cell suspension were added to precleaned slides, air dried and chromosomes stained with diluted Giemsa $(1: 20)$ and evaluated by a single observer. A total of 100 well-spread metaphase cells (50 cells per tube) with $40 \pm 2$ chromosomes per animal were scored for gaps, breaks, deletions, fragments, chromatid exchanges and ring chromosomes (Carrano and Natarajan, 1988). Chromosome and chromatid aberrations were scored separately and the total percentage of abnormal cells were expressed for statistical analysis (Sharief et al., 1986). Gaps were recorded but not included in the total CA frequency. Mitotic in- 
dices (MI) were estimated from 1000 cells / animal and expressed as percentages.

\section{In vitro lymphocyte assays}

Blood was drawn from untreated male mice and added to culture tubes as described above. After $21 \mathrm{~h}$, the original medium was replaced with fresh medium and test epoxides in DMSO $(0.01 \mathrm{ml} / \mathrm{ml}$ medium $)$ were added at the concentrations indicated in Table 2 prior to incubation again for $24 \mathrm{~h}$. The negative control was DMSO $(0.01 \mathrm{ml} / \mathrm{ml})$ and the positive control was EMS $(10 \mu \mathrm{g} / \mathrm{ml}$ ). Culture tubes (2 from each of 3 animals) were prepared for each concentration of the epoxides as well as for the controls and 50 metaphase cells per tube (100 cells per animal) were scored as described above.

\section{Results and discussion}

$\mathrm{CA}$ frequencies and MI values for the lymphocytes of mice exposed to the 4 epoxides are shown in Table 1 . The dose of $25 \mathrm{mg} / \mathrm{kg}$ for the comparison of compounds was based upon the dose-genotoxicity relationships found for these epoxides in our in vivo bone-marrow tests (Giri et al., 1989). In this in vivo/in vitro chromosomal assay, the epoxides GNE, GNPE and NPO but not TCPO caused a significant increase in the percentage of abnormal cells at $25 \mathrm{mg} / \mathrm{kg}$ when compared to their negative control. The most frequent aberrations were chromatid breaks. The order of genotoxicity by percentage of abnormal cells was $\mathrm{GNE} \cong \mathrm{NPO}>\mathrm{GNPE} \cong \mathrm{TCPO}$ with a significant increase $(p<0.01)$ being established between NPO and GNPE. All 4 epoxides produced a significant decrease in MI.

In the in vitro assay, all the test epoxides produced a significant increase $(p<0.01)$ in the percentage of $\mathrm{CA}$ at all the concentrations examined compared to the negative control (Table 2). GNE, GNPE and NPO were toxic to cells and no metaphase cells could be observed at the next highest concentration tested $(25 \mu \mathrm{g} / \mathrm{ml})$ while TCPO was toxic at $15 \mu \mathrm{g} / \mathrm{ml}$ after the $24-\mathrm{h}$ treatment period. MI values decreased significantly $(p<0.01)$ at all concentrations. A concentration-response relationship of $\mathrm{CA}$ was indicated for the 4 aliphatic epoxides where the slopes were GNPE, 0.37; NPO, 0.43; GNE, 0.45 and TCPO (based on the lowest 3 concentrations) $0.64 \mu \mathrm{g} / \mathrm{ml}$. The order of genotoxicity in CA levels at the common concentration of $5 \mu \mathrm{g} / \mathrm{ml}$ and by comparing slopes was TCPO $>\mathrm{GNE} \cong$ NPO $>$ GNPE.

The results of the present studies on cultured

TABLE 1

CHROMOSOMAL ABERRATIONS IN MOUSE LYMPHOCYTE CULTURES INDUCED BY 4 ALIPHATIC EPOXIDES 24 h AFTER TREATMENT IN VIVO

\begin{tabular}{|c|c|c|c|c|c|c|}
\hline \multirow[t]{3}{*}{ Treatment ${ }^{a}$} & \multirow[t]{3}{*}{ Gaps $/ 100$ cell $^{b}$} & \multicolumn{3}{|c|}{ Aberrations/cell } & \multirow{3}{*}{$\begin{array}{l}\text { Aberrant cells }(\%)^{c} \\
(\text { Mean } \pm \text { S.D. })^{d}\end{array}$} & \multirow{3}{*}{$\begin{array}{l}\text { Mitotic } \\
\text { indices } \\
(\text { Mean } \pm \text { S.D.) }\end{array}$} \\
\hline & & \multicolumn{2}{|c|}{ Chromatid } & \multirow[t]{2}{*}{ Chromosome } & & \\
\hline & & Break & Exchange & & & \\
\hline $\begin{array}{l}\text { DMSO }(2 \mathrm{ml} / \mathrm{kg}) \\
\quad \text { (solvent control) }\end{array}$ & 2.67 & 0.020 & 0.000 & 0.000 & $2.00 \pm 1.00$ & $2.82 \pm 0.16$ \\
\hline GNE & 4.67 & 0.040 & 0.000 & 0.013 & $5.33 \pm 0.58 * *$ & $1.97 \pm 0.15 * *$ \\
\hline $\mathrm{NPO}$ & 4.33 & 0.053 & 0.000 & 0.000 & $5.33 \pm 0.58 * *$ & $1.70 \pm 0.09 * *$ \\
\hline GNPE & 4.00 & 0.037 & 0.000 & 0.000 & $3.66 \pm 0.58 *$ & $2.19 \pm 0.18 * *$ \\
\hline ТСРО & 3.66 & 0.030 & 0.000 & 0.000 & $3.00 \pm 1.00$ & $2.24 \pm 0.27 * *$ \\
\hline \multicolumn{7}{|l|}{$\mathrm{CP}$} \\
\hline (positive control) & 5.00 & 0.110 & 0.000 & 0.000 & $11.00 \pm 1.00 * *$ & $1.69 \pm 0.32 * *$ \\
\hline
\end{tabular}

a Each compound was tested at $25 \mathrm{mg} / 2 \mathrm{ml} \mathrm{DMSO} / \mathrm{kg}$ of body weight.

b Total chromatid and chromosome gaps $/ 100$ cells at each concentration were recorded but not included as aberrations.

c Cells with at least 1 aberration. Results are for 3 animals at each concentration (100 cells/animal).

${ }^{d}$ Results for each chemical were compared to those of solvent control using Student's $t$-test $\left({ }^{*} p<0.05\right.$ and $\left.* * p<0.01\right)$. 
TABLE 2

CHROMOSOMAL ABERRATIONS IN MOUSE LYMPHOCYTE IN VITRO CULTURES INDUCED BY 4 ALIPHATIC EPOXIDES AFTER 24-h TREATMENT

\begin{tabular}{|c|c|c|c|c|c|c|}
\hline \multirow{3}{*}{$\begin{array}{l}\text { Treatment } \\
\text { concentration } \\
(\mu \mathrm{g} / \mathrm{ml} \text { culture })\end{array}$} & \multirow[t]{3}{*}{ Gaps $/ 100$ cell $^{a}$} & \multicolumn{3}{|c|}{ Aberrations/cell } & \multirow{3}{*}{$\begin{array}{l}\text { Aberrant cells }(\%)^{b} \\
\text { (Mean } \pm \text { S.D.) }\end{array}$} & \multirow{3}{*}{$\begin{array}{l}\text { Mitotic } \\
\text { indices } \\
\text { (Mean } \pm \text { S.D.) }\end{array}$} \\
\hline & & \multicolumn{2}{|c|}{ Chromatid } & \multirow[t]{2}{*}{ Chromosome } & & \\
\hline & & Break & Exchange & & & \\
\hline \multicolumn{7}{|c|}{ DMSO $(0.01 \mathrm{ml} / \mathrm{ml}$ culture $)$} \\
\hline (solvent control) & 3.33 & 0.017 & 0.000 & 0.000 & $1.67 \pm 0.058$ & $2.51 \pm 0.31$ \\
\hline \multicolumn{7}{|l|}{ TCPO } \\
\hline 1 & 4.67 & 0.033 & 0.007 & 0.007 & $4.67 \pm 0.58 * * \mathrm{c}$ & $1.76 \pm 0.17 * * \mathrm{c}$ \\
\hline 2.5 & 5.33 & 0.053 & 0.003 & 0.007 & $6.33 \pm 0.58$ & $1.58 \pm 0.20$ \\
\hline 5 & 6.00 & 0.062 & 0.000 & 0.020 & $7.33 \pm 1.16$ & $1.32 \pm 0.13$ \\
\hline 10 & 6.33 & 0.060 & 0.007 & 0.020 & $8.67 \pm 0.58$ & $1.12 \pm 0.09$ \\
\hline \multicolumn{7}{|l|}{ NPO } \\
\hline 5 & 5.00 & 0.050 & 0.003 & 0.010 & $6.33 \pm 0.58 * *$ & $1.59 \pm 0.26 * *$ \\
\hline 10 & 6.33 & 0.077 & 0.003 & 0.020 & $9.00 \pm 1.00$ & $1.25 \pm 0.22$ \\
\hline 15 & 6.67 & 0.077 & 0.007 & 0.030 & $10.67 \pm 0.58$ & $0.99 \pm 0.27$ \\
\hline \multicolumn{7}{|l|}{ GNE } \\
\hline 5 & 6.33 & 0.050 & 0.003 & 0.010 & $6.33 \pm 0.58 * *$ & $1.73 \pm 0.17 * *$ \\
\hline 10 & 6.00 & 0.073 & 0.000 & 0.010 & $8.33 \pm 0.58$ & $1.44 \pm 0.30$ \\
\hline 15 & 5.33 & 0.090 & 0.000 & 0.020 & $11.00 \pm 1.00$ & $1.25 \pm 0.20$ \\
\hline \multicolumn{7}{|l|}{ GNPE } \\
\hline 5 & 4.33 & 0.040 & 0.000 & 0.013 & $5.33 \pm 0.58 * *$ & $1.67 \pm 0.17 * *$ \\
\hline 10 & 6.00 & 0.063 & 0.000 & 0.010 & $7.33 \pm 0.58$ & $1.27 \pm 0.21$ \\
\hline 15 & 5.67 & 0.070 & 0.003 & 0.017 & $9.00 \pm 1.00$ & $0.97 \pm 0.12$ \\
\hline \multicolumn{7}{|c|}{ EMS (positive control) } \\
\hline 10 & 6.33 & 0.063 & 0.000 & 0.020 & $6.33 \pm 1.16 * *$ & $1.67 \pm 0.10 * *$ \\
\hline
\end{tabular}

a Total chromatid and chromosome gaps / 100 cells at each concentration were recorded but not included as aberrations.

${ }^{b}$ Cells with at least 1 aberration. Results are for 3 animals at each concentration (100 cells / animal).

c Indicates lowest concentration tested where the results were significantly different than the negative control, $* * p<0.01$ using Dunnett's test.

mouse lymphocytes subsequent to either in vivo or in vitro exposure to the aliphatic epoxides were compared to our previous in vivo genotoxicity studies of the same epoxides. The end points of the previous studies were CA and SCE effects in bone-marrow cells (Giri et al., 1989) and DNA strand-break analysis of liver cells (Giri et al., 1990) following i.p. administration of the epoxides to mice. There was about a 4-fold increase in sensitivity for the lymphocyte assay following i.p. administration compared to the in vivo bone-marrow cell examination for CA. That is, CA values for $25 \mathrm{mg} / \mathrm{kg}$ i.p. doses in the lymphocyte assay are comparable to the bone-marrow cell results for CA at $100 \mathrm{mg} / \mathrm{kg}$ of epoxide. The relative CA values in the two in vivo assays are similar with those for GNE being among the highest and those for TCPO the lowest.

As expected there was an even greater increase in sensitivity when the epoxides were added directly to cultured lymphocytes, as compared to the CA assays following in vivo administration of the same compounds. There is, however, a change in the relative order of CA values for the epoxides with TCPO having the greatest effect in the in vitro tests as opposed to the least effect following i.p. administration. This change in the relative order of genotoxicity was also evident in comparing our previous in vivo strand-break results in liver cells to those of the in vivo bone-marrow studies. As indicated for these comparisons (Giri et al., 1990), the relative stability of the epoxides 
in vivo is a major factor in explaining the relative order of genotoxicity. TCPO, the most chemically reactive of these epoxides, has a short half-life (Norppa et al., 1981; Giri et al., 1990) and is rapidly detoxified by liver glutathione transferase and hydrolase systems (Sinsheimer et al., 1987). Compounds are absorbed from the peritoneum via the portal system (Lukas et al., 1971) and rapidly reach the liver (Dedrick et al., 1978). Therefore, differences in the relative rates of detoxication of epoxides would be expected to have a pronounced influence on relative genotoxicity at remote sites such as bone-marrow cells or lymphocytes in vivo as compared to the direct in vitro addition of the epoxides to cultured lymphocytes. The present study, with its direct comparison of CA results for lymphocytes following in vivo or in vitro exposure, again emphasizes the importance of evaluating relative half-lives of direct-acting alkylating agents.

\section{Acknowledgments}

This investigation was supported by Grant R01ES03345 from the National Institute of Environmental Health Sciences, DHHS.

\section{References}

Abrahams, R.H. (1980) Recent studies with workers exposed to ethylene oxide, in: J.F. Jorkaeky (Ed.), The Safe Use of Ethylene Oxide, Proceedings Manufacture Association, Washington, DC.

Carrano, A.V., and A.T. Natarajan (1988) Consideration for population monitoring using cytogenetic techniques, $\mathrm{Mu}$ tation Res., 204, 379-406.

Davisson, M.T., and E.C. Akeson (1987) An improved method for preparing G-banded chromosomes from mouse peripheral blood, Cytogenet. Cell Genet., 45, 70-74.

Dedrick, R.L., C.E. Myers, P.M. Bungay and V.T. DeVita (1978) Pharmacokinetic rationale for peritoneal drug administration in the treatment of ovarian cancer, Cancer Treat. Rep., 62, 1-9.

De Raat, W.K. (1978) Induction of sister chromatid exchanges by styrene and its presumed metabolite styrene oxide in the presence of rat liver homogenate, Chem.-Biol. Interact., $20,163-170$.

Djuric, Z., B.H. Hooberman, L.B. Rosman and J.E. Sinsheimer (1986) Reactivity of mutagenic propylene oxides with deoxynucleotides and DNA, Environ. Mutagen., 8, 369-383.

Ehrenberg, L., and T. Hallstrom (1967) Haematologic studies in persons occupationally exposed to ethylene oxide, in:
Radiosterilization of Medical Products, International Atomic Energy Agency, Vienna, pp. 327-334.

Ehrenberg, L., and S. Hussain (1981) Genetic toxicity of some important epoxides, Mutation Res., 86, 1-113.

Garry, V.F., J. Hozier, D. Jacob, R.L. Wade and D.G. Gray (1979) Ethylene oxide: Evidence of human chromosomal effects, Environ. Mutagen., 1, 375-382.

Giri, A.K., E.A. Messerly and J.E. Sinsheimer (1989) Sisterchromatid exchange and chromosome aberrations for 4 aliphatic epoxides in mice, Mutation Res., 224, 253-261.

Giri, A.K., E.A. Messerly, P.K. Chakraborty, B.H. Hooberman and J.E. Sinsheimer (1990) DNA strand breaks in liver for four aliphatic epoxides in mice, Mutation Res., 242, 187-194.

Högstedt, B., B. Gullberg, K. Hedner, A.M. Kolnig, F. Mitelman, S. Skerfving and B. Widegren (1983) Chromosome aberrations and micronuclei in bone marrow cells and peripheral blood lymphocytes in humans exposed to ethylene oxide, Heriditas, 98, 105-113.

Högstedt, B., E. Bergmark, M. Törnqvist and S. OstermanGolkar (1990) Chromosomal aberrations and micronuclei in lymphocytes in relation to alkylation of hemoglobin in workers exposed to ethylene and propylene oxide, Heriditas, 113, 133-139.

Kligerman, A.D., G.L. Erexson, M.E. Phelps and J.L. Wilmer, (1983) Sister-chromatid exchange induction in peripheral blood lymphocytes of rats exposed to ethylene oxide by inhalation, Mutation Res., 120, 37-44.

Lerda, D., and R. Rizzi (1992) Cytogenic study of persons occupationally exposed to ethylene oxide, Mutation Res., 281, 31-37.

Lukas, G., S.D. Brindle and P. Greengard (1971) The route of absorption of intraperitoneally administered compounds, J. Pharmacol. Exp. Ther., 178, 562-566.

Lynch, D.W., T.R. Lewis, W.J. Moorman, J.R. Burg, D.K. Gulanti, P. Kaur and P.S. Sabharval (1984) Sister-chromatid exchanges and chromosome aberrations in lymphocytes from monkeys exposed to ethylene oxide and propylene oxide by inhalation, Toxicol. Appl. Pharmacol., 76, 85-96.

Manson, M.M. (1980) Epoxides - is there a human health problem? Br. J. Indust. Med., 37, 317-336.

Neau, S.H., B.H. Hooberman, S.W. Frantz and J.E. Sinsheimer (1982) Substituent effects on the mutagenicity of phenyl glycidyl ethers in Salmonella typhimurium, Mutation Res., 93, 297-304.

Nishi, Y., M.M. Hasegawa, M. Taketomi, Y. Ohkawa and N. Inui (1984) Comparison of 6-thioguanine-resistant mutation and sister chromatid exchanges in Chinese hamster V79 cells with forty chemical and physical agents, Cancer Res., 44, 3270-3279.

Norppa, H., K. Hemminki, M. Sorsa and H. Vainio (1981) Effect of monosubstituted epoxides on chromosome aberrations and SCE in cultured human lymphocytes, Mutation Res., 91, 243-250.

Rosman, L.B., V. Gaddamidi and J.E. Sinsheimer (1987) Mutagenicity of aryl propylene and butylene oxides with Salmonella, Mutation Res., 189, 189-204. 
Rosman, L.B., P.K. Chakraborty, E.A. Messerly and J.E. Sinsheimer (1988) Mutagenicity of aromatic glycidyl ethers with Salmonella, Mutation Res., 206, 115-125.

Sasiadek, M., J. Jarventaus and M. Sorsa (1991a) Sister-chromatid exchanges induced by 1,3-butadiene and its epoxides in CHO cells, Mutation Res., 263, 47-50.

Sasiadek, M., H. Norppa and M. Sorsa (1991b) 1,3-Butadiene and its epoxides induced sister-chromatid exchanges in human lymphocytes in vitro, Mutation Res., 261, 117-121.

Sharief, Y., A.M. Brown, L.C. Backer, J.A. Campbell, B. Westbrook-Colling, A.G. Stead and J.W. Allen (1986)
Sister chromatid exchange and chromosome aberration analyses in mice after in vivo exposure to acrylonitrile, styrene, or butadiene monoxide, Environ. Mutagen., 8, 439-448.

Sinsheimer, J.E., E. Van den Eeckhout, B.H. Hooberman and V.G. Beylin (1987) Detoxication of aliphatic epoxides by diol formation and glutathione conjugation, Chem.-Biol. Interact., 63, 75-90.

Wade, D.R., S.C. Airy and J.E. Sinsheimer (1978) Mutagenicity of aliphatic epoxides, Mutation Res., 58, 217-223. 